ARAŞTIRMA MAKALESI

\title{
Tarım İşçilerinin Covid-19 Pandemisinde Kişisel Koruyucu Kullanımı Farkındalıkları, Sağlık Endişeleri ve Anksiyeteleri
}

\author{
İlknur AYDIN AVCI ${ }^{1}$, (iD) Ayla HENDEKCI ${ }^{2}$
}

${ }^{1}$ Prof. Dr., Ondokuz Mayıs Üniversitesi Sağlık Bilimleri Fakültesi Hemşirelik Bölümü, Samsun, Türkiye

${ }^{2}$ Dr. Arş. Gör., Giresun Üniversitesi Sağlık Bilimleri Fakültesi Hemşirelik Bölümü, Giresun, Türkiye

\section{Öz}

Giriş: Pandemi önemli bir halk sağlığı sorunudur. Toplumda bazı grupların pandemi sürecinde daha fazla bilgiye ve farkındalığa ihtiyaç duyduğu, endişe ve anksiyete yaşadıkları düşünülmektedir. Tarım işçileri bu gruplardan biri olarak halk sağlığı hemşirelerinin değerlendirmesi ve uygun yaklaşımlar geliştirmesi açısından önemlidir. Amaç: Bu çalışmada amaç, tarım işçilerinin Covid-19 pandemisinde kişisel koruyucu kullanımına yönelik farkındalıkları, sağlıkla ilgili endişeleri ve anksiyetelerini belirlemektir. Yöntem: Tanımlayıcı türdeki çalışmanın evrenini Doğu Karadeniz bölgesindeki bir ilde bulunan findık işçileri oluşturmaktadır $(\mathrm{n}=153)$. Veri toplama araçları olarak 'Bilgi Formu, Covid-19 Korkusu Ölçeği ve Beck Anksiyete Ölçeği’ kullanılmıştır. Veriler, online olarak toplanmıştır. İstatistiksel değerlendirme SPSS paket programı yardımıyla normal dağılıp dağılmadığı belirlenerek, t-testi/Mann Withney U testi ve ANOVA/Kruskall Wallis testi ile yapılmıştır. Bulgular: Çalışmaya katılan tarım işçilerinin yaş ortalaması $36.34 \pm 12.69, \% 50.3$ 'ü kadın ve \%53.6'sı üniversite mezunudur. İşçilerin \%33.1'i Covid19 ile ilgili yapılması gereken iyileştirmelerin başında hijyen koşulları olduğunu düşünmekte, \%43.8'i sosyal mesafeye dikkat konusunda kararsız kalmakta, \%49.7'si maske kullanımına dikkat edilemediğini düşünmektedir. İşçilerin \%54.9'u hastalığın kendilerine bulaşacağını ve \%84.3'ü kendilerini güvende hissetmediklerini belirtmektedir. İşçilerin Covid-19 Korkusu Ölçeği puanı $17.62 \pm 6.06$ iken Beck Anksiyete Ölçeği puanı $12.47 \pm 11.13$ 'tür. Sonuç: Çalışmada tarım işçilerinin Covid-19 korkularının şiddetli olduğu, anksiyetelerinin normal düzeyde olduğu ve cinsiyet, aile yapısı, gelir düzeyi gibi demografik değişkenlere göre değiştiği bulunmuştur. Kişisel koruyucu kullanımı, sosyal mesafe ve vardiyalı çalışma durumları ile korku ve endişeleri arasında ilişki olduğu bulunmuştur. Sahadaki risklerin belirlenmesi, uygun önlemlerin alınması, etkin bir kontrol mekanizması sağlanması ve işbirliği içinde hareket edilmesi önerilmektedir.

Anahtar Sözcükler: Covid-19, Endişe, Korku, Kişisel Koruyucu Kullanımı, Pandemi, Tarım Işçileri.

Abstract
Awareness, Health Concerns and Anxiety Situations of Agricultural Workers Regarding the Use of Personal Protective
Equipment in the COVID-19 Pandemic
Background: Pandemic is an important public health problem and some groups are believed to experience anxiety and need increased
awareness during the pandemic process. As one of them, agricultural workers are important for public health nurses to evaluate and develop
appropriate approaches. Objectives: Study aims to identify awareness, health concerns and anxiety of agricultural workers regarding the
use of personal protective equipment in the pandemic. Methods: Study population of this descriptive research consists of hazelnut
workers in a province in the Eastern Black Sea region (n $=153$ ). Personal Information Form, The Fear of COVID-19 Scale, and Beck
Anxiety Inventory were used for online data collection. After testing normality with the SPSS package program, statistical evaluation was
performed using the t-test/Mann-Whitney U and ANOVA/Kruskal Wallis tests. Results: Average age of workers was $36.34 \pm 12.69$,
$50.3 \%$ was female, $53.6 \%$ was a university graduate, $33.1 \%$ believes improved hygiene is necessary, $43.8 \%$ was undecided about social
distance, and $49.7 \%$ believes it's hard to pay attention to use masks. Of them, 54.9\% states they will get infected, $84.3 \%$ does not feel
safe. The FCV-19S score was $17.62 \pm 6.06$ and BAI score was $12.47 \pm 11.13$. Conclusion: Agricultural workers were found to have
intense COVID-19 fears and normal level of anxiety, varying with demographic variables such as gender, family structure, and income
level. Relationship was found between use of personal protective, social distance, shift work and their fear and anxiety. It is recommended
to identify risks in the field, take appropriate measures, provide an effective control mechanism and act in cooperation.
Key Words: COVID-19, Anxiety, Fear, Use of Personal Protective, Pandemic, Agricultural Workers.

Geliș Tarihi / Received: 30.10.2020 Kabul Tarihi / Accepted: 09.08.2021

Correspondence Author: Dr. Arş. Gör., Giresun Üniversitesi Sağlık Bilimleri Fakültesi Hemşirelik Bölümü, Giresun, Türkiye. Telefon: 05393570628 E-posta: ayla.hendekci@gmail.com

Cite This Article: Aydın Avcı İ, Hendekci A. Tarım İsç̧ilerinin Covid-19 Pandemisinde Kișisel Koruyucu Kullanımı Farkındalıkları, Sağlık Endișeleri ve Anksiyeteleri Dokuz Eylül Üniversitesi Hemşirelik Fakültesi Elektronik Dergisi. 2021; 14 (4): 337- 347 
C in'de ortaya çıkan 'Coronavirüs' olarak tanımlanan virüs, bir süre sonra dünya geneline yayılmıştır. Enfekte kişi sayısındaki artışla birlikte Dünya Sağlık Örgütü tarafından pandemi olarak ilan edilmiştir. Vaka sayılarının gün geçtikçe artmasıyla birlikte süreç hem ülkeler hem de toplumlar için çeşitli sorunların ortaya çıkması ile devam etmektedir. Dünyanın geçmiş yıllarda kolera, veba, ispanyol gribi gibi benzer pandemi deneyimleri yaşadığı, bu deneyimlerden yola çıkılarak toplum genelinde sağlıkla ilgili bazı endişe, korku ve anksiyete durumlarının oluşabileceği öngörülmektedir (1-3). Toplum içinde yaşam şartları olarak farklı özelliklere sahip risk grupları (göçmenler, engelliler, yaşlılar, adölesanlar gibi sağlık kaynaklarından sınırlı yararlanan bireyler) vardır. Bu gruplardan biri de tarım işçileridir (4).

Uluslararası Çalışma Örgütü’nün yaptı̆̆ı tanıma göre, tarım işçileri ‘kırsal kesimde tarım, zanaat ya da benzeri bir işte çalışan kişiler'dir (5). Tarım işçileri çeşitli özelliklerine göre farklı şekillerde sınıflandırılmaktadır. Buna göre tarım işçileri çalışma süresi, yaşadığı yer ve uyruğuna göre üç başlıkta ele alınmaktadır (6). Çalışma süresine göre, sürekli ve geçici iş̧̧i; uyruğuna göre, yerli ve yabancı işçi; yaşadığı yere göre yerli ve gezici olarak farklı disiplinlerce farklı şekillerde sınıflandırılabilmektedir (7). Tarım iş̧̧ilerinden biri, findık üretiminde çalıșan bireylerdir ve fındık üretiminde her yıl binlerce işçi çalışmaktadır. Fındık tarımı, emeğin yoğun olduğu ve kalabalık kitleleler halinde çalışılan üretimlerin başında gelmektedir. Fındık işçilerinin hasat boyunca çoğunluğunun ücretsiz aile işçisi olarak çalıştığı bilinmektedir (8). Bu kişilerin yaşam ve çalışma koşulları olarak farklı düzeylerde zorluklara maruz kaldıkları bilinmektedir (9). Bu zorluklar çoğunlukla beslenme, hareket, barınma, eğitim ve sağlıkla ilgilidir (10). Pandemi süresince işçilerin yaşam ve çalışma koşullarında zorluklar yaşanacağı düşünülmektedir. Bu süreçte toplumun genelinde özellikle risk gruplarında fiziksel ve psikolojik etkilerin görüldüğü bilinmekte, bunların başında sağlıkla ilgili endişe ve anksiyete durumları yer almaktadır (11).

Literatürde toplum içinde farklı popülasyonlarda endișe, korku ve anksiyete düzeyleri ile ilişkili yapılmıș çalışmalara rastlanmaktadır (12-14). Aynı zamanda toplu halde çalışan işçilerin enfeksiyon açısından risk altında olduğu, olumsuz sağlık koşullarına maruz kaldığı ifade edilmektedir $(10,15,16)$. Fakat tarım iş̧̧ileri ile yapılan benzer bir çalışmaya ulaşılmamıştır. Güncel olan pandemi süresince kalabalık olarak çalışan ve risk altında olan tarım işçilerinin farkındalıkları ile yaşadıkları endişe ve anksiyete durumlarının belirlenmesi halk sağlığı açısından oldukça önemlidir. Bu çalışmada amaç, tarım işçilerinin Covid-19 pandemisinde kişisel koruyucu kullanımına yönelik farkındalıkları, sağlıkla ilgili endişe ve anksiyete durumlarını belirlemektir.

Araştırmanin Soruları

- Tarım işçilerinin Covid-19 pandemisinde kişisel koruyucu kullanımına yönelik farkındalıkları nedir?

- Tarım işçilerinin Covid-19 pandemisinde sağlıkla ilgili endişeleri ve anksiyeteleri ne düzeydedir?

- Tarım işçilerinin kişisel koruyucu kullanımına yönelik farkındalıklarına göre endişe ve anksiyeteleri arasında ilişkili var midır?

\section{Araştırmanın Tipi}

Yöntem

Bu çalıșma tanımlayıcı türdedir.

Araştırmanın Yapıldığı Yer ve Zaman

Bu çalışma, 2020 yılı findık hasatı tarihinden sonra Kasım-Aralık aylarında Doğu Karadeniz Bölgesi’ndeki fındık üretiminin en yoğun olduğu bir ilde bulunan findık işçileri ile gerçekleştirilmiş̧ir.

\section{Araştırmanin Değişkenleri}

Araştırmanın bağımlı değiş̧keni çalışma kapsamındaki öğrencilerin "Hemşirelik Öğrencileri İçin Kişisel Sağlık Verilerinin Kayıt ve Korunması Tutum Ölçeği" puan ortalamalarıdır. Araştırmanın bağımsız değişkenleri ise çalışma kapsamındaki öğrencilerin sosyo-demografik özellikleri, hemşirelik bölümünü isteyerek tercih etme durumu, uygulama alanlarında çalışmayı sevme durumu ve hastalarla iletişim düzeyi, kişisel veri ve kişisel sağlık verisi kavramını daha önce duyma durumudur.

\section{Araştırmanın Evreni/Örneklemi}

Çalışmanın evreni fındık iş̧̧ilerinden oluşmaktadır. Örneklem, evren sınırlarının kesin olarak belirlenemediği durumlarda kullanılan kartopu örnekleme ile belirlenmiştir (17). Eksik ya da hatalı doldurulan ölçekler nedeniyle 9 kişi araştırmaya dahil edilmemiş ve 153 kişi ile çalışma tamamlanmıştır $(n=153$.) Araştırma için dahil edilme kriterleri; findık iş̧̧isi olmak, iletişime açık olmak ve araştırmaya katılmaya gönüllü olmaktır.

\section{Araştırmanin Değişkenleri}

Bağımlı değişken: Tarım işçilerinin Covid-19 korkusu ve anksiyete düzeyleridir.

Bağımsız değişken: Tarım işçilerinin Covid-19 ile ilgili bilgileri, kişisel koruyucu kullanımına yönelik farkındalıkları, sosyodemografik bazı özellikleridir

\section{Veri Toplama Araçlart}

Bu çalışmada veriler 'Bilgi Formu, Covid-19 Korkusu Ölçeği ve Beck Anksiyete Ölçeği’ ile toplanmıştır.

Bilgi Formu

Araştırmacılar tarafindan hazırlanan bu form 24 sorudan oluşmaktadır. Formda yer alan bu sorular sosyodemografik özelliklerin yanı sıra Covid-19 bilgi düzeyi ve kişisel koruyucu kullanımına yönelik farkındalığı ölçen özelliktedir $(11,12,18)$.

Covid-19 Korkusu Ölçeği

Ahorsu ve arkadaşlarının (2020) geliştirdiği ölçek Türkçe'ye Bakioğlu, Korkmaz ve Ercan (2020) tarafindan uyarlanmıştır. Yedi sorudan oluşan ölçek 5'li likert $(1=$ Kesinlikle katılmıyorum, $5=$ Kesinlikle katılıyorum) türündedir. Ölçek tek boyuttan oluşmaktadır. Ölçekten alınabilecek puanlar 7 ile 35 arasında değişmektedir. Ölçeğin 
tüm maddelerinden alınan toplam puan bireyin yaşadığı Covid-19 korkusu düzeyini yansıtmaktadır. Alınan yüksek puan yüksek düzeyde korku yaşamak anlamına gelmektedir. Ölçek Cronbach Alpha değeri .88'dir (19,20). Bu çalışma için Cronbach Alpha değeri .88'dir.

Beck Anksiyete Ölçeği

Beck ve arkadaşlarının (1988) geliştirdiği ölçek, bireylerin yaşadığı anksiyete belirtilerini belirlenmek amacıyla kullanılmaktadır. Türkçe geçerlik güvenirliği Ulusoy ve arkadaşları (1998) tarafından yapılmıştır. Yirmi bir maddeden oluşan ölçek 4'lü likert $(0=$ Hiç, 3 = Ciddi Derecede) türündedir. Ölçekten en düşük 0 , en yüksek 63 puan alınabilmektedir. Ölçekten alınan yüksek puan, yaşanan anksiyetenin yüksek olduğunu göstermektedir. Ölçekten alınan toplam puana göre normal ile ciddi anksiyete arasında değerlendirme yapılmaktadır. Ölçek Cronbach Alpha değeri .93'tür $(21,22)$. Bu çalışma için Cronbach Alpha değeri .94'tür

\section{Verilerin Toplanmast}

Veriler, online bir form aracılığıyla toplanmıştır. Online formun içinde onam ve çalışmada kullanılan ölçekler yer almaktadır. Bu form çalışmanın yapıldığı tarih aralığında katılımcılara açık olacak şekilde kişilere ulaştırılmış sonrasında erişime kapatılmıştır. Kişisel verilerin korunması kanununa uyulmuştur.

\section{Verilerin Değerlendirilmesi}

Araştırma sonucunda elde edilen veriler araştırmacılar tarafindan bilgisayar ortamında ve istatistiksel çözümlemeler için Çalışmanın istatistiksel analizleri SPSS 24.00 paket programı ile yapılmıştır. Analizlerde, verilerin normal dağılıp dağılmadığ 1 Kolmogorov Simirnov testi ile belirlenerek t-testi/Mann Withney U testi ve ANOVA/Kruskall Wallis testi kullanılmıştır. Araştırmada anlamlılık düzeyi $\mathrm{p}<.05$ olarak kabul edilmiştir.

Araştırmanın Etik Yönü

Bir üniversitenin Sosyal ve Beşeri Bilimler Etik Kurulu'ndan (Karar Sayısı: 2020/665) etik onay alınmıştır. Çalışmada Helsinki Bildirgesine sadık kalınmış ve katılımcılardan yazılı onay alınmıştır. Çalışmada kullanılan ölçeklerin yazarlarından e-mail yoluyla izin alınmıştır. Çalışmada, araştırma ve yayın etiğine uyulmuştur.

\section{Bulgular}

Bu çalışmadaki tarım işçilerinin bazı tanıtıcı özellikleri şu şekildedir; işçilerin yaş ortalaması $36.34 \pm 12.69$ (min-max: 16.00-71.00), \%50.3'ü kadın ve \%53.6'sı üniversite mezunudur. Çalışmaya katılan tarım işçilerinin \% 74.5'i ücretsiz aile işçisidir. Tarım işçilerinin \%68.6'sının geliri giderine denk, \%79.1'i çekirdek aile yapısında ve \%43.8'i bir ilçede yaşamaktadır. Tarım işçilerinin \%26.8'i kronik bir hastalığa sahiptir. Tarım işçilerinin \%33.1'i Covid-19 ile ilgili yapılması gereken iyileştirmelerin hijyen koşulları olduğunu düşünmektedir.

Tablo 1. Tarım İşçilerinin Beck Anksiyete Ölçeği ve Covid-19 Korkusu Ölçek Puanları (n=153)

\begin{tabular}{lcc} 
& $\mathbf{X} \pm \mathbf{S S}$ & Min-Max \\
\cline { 2 - 3 } Covid-19 Korkusu Ölçeği & $\mathbf{n}$ & $7-34$ \\
Beck Anksiyete Ölçeği & $17.62 \pm 6.06$ & $0-42$ \\
Normal & $12.47 \pm 11.13$ & 51.6 \\
Hafif Anksiyete (10-18) & 79 & 19.0 \\
Orta Anksiyete (19-29) & 29 & 17.6 \\
Ciddi Anksiyete (30-63) & 27 & 11.8 \\
\hline
\end{tabular}

Tablo 1'e göre, tarım işçilerinin Covid-19 korkusu ölçeği puan ortalaması $17.62 \pm 6.06$ olarak bulunmuştur. Beck anksiyete ölçeği puan ortalaması 12.47 11.13 olarak bulunmuştur. Beck anksiyete ölçeğine göre tarım işçilerinin \%51.6's1 normal iken \%11.8'i ciddi anksiyeteye sahiptir. 
Tablo 2. Tarım İşcilerinin Sosyodemografik Özelliklerine Göre Covid-19 Korkusu Ölçeği ve Beck Anksiyete Ölçeği Puan Dă̆ılımı (n=153)

\begin{tabular}{|c|c|c|}
\hline & $\begin{array}{c}\text { Covid-19 Korkusu Ölçeği } \\
\quad X \pm S S \\
\end{array}$ & $\begin{array}{c}\text { Beck Anksiyete Ölçeği } \\
\qquad \pm \text { SS }\end{array}$ \\
\hline \multicolumn{3}{|l|}{ Cinsiyet } \\
\hline Kadın & $2.66 \pm .90$ & $.65 \pm .54$ \\
\hline Erkek & $2.33 \pm .79$ & $.53 \pm .50$ \\
\hline Test/P & $\mathrm{U}=\mathbf{2 2 7 3 . 5 0 0} \mathrm{p}=.017$ & $\mathrm{U}=2543.500 \mathrm{p}=.162$ \\
\hline \multicolumn{3}{|l|}{ Gelir durumu } \\
\hline Gelir giderden az & $3.16 \pm .94$ & $.82 \pm .57$ \\
\hline Gelir gidere denk & $2.39 \pm .78$ & $.55 \pm .48$ \\
\hline Gelir giderden fazla & $2.46 \pm .89$ & $.57 \pm .64$ \\
\hline Test/P & $K W=12.367 p=.002$ & $\mathrm{KW}=4.914 \mathrm{p}=.086$ \\
\hline \multicolumn{3}{|l|}{ Aile yapısı } \\
\hline Çekirdek aile & $2.51 \pm .88$ & $.52 \pm .49$ \\
\hline Geniş aile & $2.51 \pm .82$ & $.85 \pm .59$ \\
\hline Test/P & $\mathrm{U}=1886.500 \mathrm{p}=.824$ & $\mathrm{U}=1298.500 \mathrm{p}=.004$ \\
\hline \multicolumn{3}{|c|}{ Uzun süre yaşanılan yer } \\
\hline İl & $2.42 \pm .76$ & $.57 \pm .51$ \\
\hline İlçe & $2.58 \pm .89$ & $.55 \pm .53$ \\
\hline Köy & $2.54 \pm .98$ & $.72 \pm .55$ \\
\hline Test/P & $\mathrm{KW}=.795 \mathrm{p}=.672$ & $\mathrm{KW}=2.598 \mathrm{p}=.273$ \\
\hline
\end{tabular}

Tablo 2'ye göre, tarım işçilerinin cinsiyetlerine göre Covid-19 korkusu ölçeği puan ortalamaları arasında istatistiksel olarak anlamlı bir fark vardır $(\mathrm{p}<.05)$. Kadın tarım işçilerinin Covid-19 korkusu ölçeği puan ortalaması erkek tarım işçilerine göre daha yüksek bulunmuştur. Gelir durumu ile Covid-19 korkusu ölçeği arasında istatistiksel olarak anlamlı bir fark vardır $(\mathrm{p}<.05)$. Geliri giderden az olan ile geliri gidere denk $(\mathrm{p}=.004)$ ve fazla $(\mathrm{p}=.033)$ olan tarım işçileri arasında istatistiksel olarak anlamlı bir fark vardır $(\mathrm{p}<.05)$. Geliri giderden az olan tarım işçilerinin Covid19 korkusu ölçeği puan ortalaması daha yüksek bulunmuştur. Aile yapısı ile Beck anksiyete ölçeği arasında istatistiksel olarak anlamlı bir fark vardır $(\mathrm{p}<.05)$. Geniş aile yapısına sahip olan tarım işçilerinin çekirdek aile yapısına sahip olanlara göre anksiyeteleri daha yüksek bulunmuştur. 
Tablo 3. Tartm İşçilerinin Covid-19 İle İlgili Bilgi Düzeylerine göre Covid-19 Korkusu Ölçeği ve Beck Anksiyete Ölçeği Puan Dağılımı (n=153)

\begin{tabular}{|c|c|c|c|c|}
\hline & $\mathbf{n}$ & $\%$ & $\begin{array}{l}\text { Covid-19 Korkusu Ölçeği } \\
\qquad \mathrm{X} \pm \mathrm{SS} \\
\end{array}$ & $\begin{array}{c}\text { Beck Anksiyete } \\
\text { Ölçeği } \\
\text { X } \pm \text { SS } \\
\end{array}$ \\
\hline \multicolumn{5}{|c|}{ Covid-19 tanısı alma durumu } \\
\hline Alan & 6 & 3.9 & $2.90 \pm .81$ & $1.10 \pm .42$ \\
\hline Almayan & 147 & $\begin{array}{c}96 . \\
1\end{array}$ & $2.50 \pm .86$ & $.57 \pm .52$ \\
\hline Test/P & & & $\mathrm{U}=303.500 \mathrm{p}=.195$ & $\mathrm{U}=\mathbf{1 9 1 . 0 0} \mathrm{p}=.019$ \\
\hline \multicolumn{5}{|c|}{ Covid-19 tanısı alan yakını olma durumu } \\
\hline Var & 37 & $\begin{array}{c}24 . \\
2\end{array}$ & $2.47 \pm .60$ & $.75 \pm .40$ \\
\hline Yok & 116 & $\begin{array}{c}75 . \\
8\end{array}$ & $2.53 \pm .93$ & $.54 \pm .55$ \\
\hline Test/P & & & $\mathrm{U}=2128.00 \mathrm{p}=.939$ & $\mathrm{U}=1400.500 \mathrm{p}=.001$ \\
\hline \multicolumn{5}{|c|}{ Covid-19 hakkında yeterli bilgiye sahip olduğunu düşünme } \\
\hline Evet & 107 & $\begin{array}{c}69 . \\
9\end{array}$ & $2.41 \pm .89$ & $.45 \pm .49$ \\
\hline Hayır & 9 & 5.9 & $2.57 \pm .97$ & $1.04 \pm .69$ \\
\hline Kararsız & 37 & $\begin{array}{c}24 . \\
2\end{array}$ & $2.80 \pm .70$ & $.88 \pm .40$ \\
\hline Test/P & & & $K W=7.737 p=.021$ & $K W=29.041 p=.00$ \\
\hline \multicolumn{5}{|c|}{ Covid-19 ile ilgili alınan bilginin kaynağı } \\
\hline Aile & 16 & $\begin{array}{c}10 . \\
5\end{array}$ & $2.63 \pm .73$ & $1.01 \pm .46$ \\
\hline Arkadaşlar & 18 & $\begin{array}{c}11 . \\
8\end{array}$ & $2.38 \pm .92$ & $.64 \pm .50$ \\
\hline Sağlık bakanlığ1 & 62 & $\begin{array}{c}40 . \\
5\end{array}$ & $2.59 \pm .97$ & $.52 \pm .53$ \\
\hline Medya kuruluşları & 39 & $\begin{array}{c}25 . \\
5\end{array}$ & $2.38 \pm .75$ & $.54 \pm .47$ \\
\hline Sosyal medya & 18 & $\begin{array}{c}11 . \\
8\end{array}$ & $2.56 \pm .79$ & $.50 \pm .58$ \\
\hline Test/P & & & $\mathrm{KW}=1.916 \mathrm{p}=.571$ & $K W=14.046 p=.007$ \\
\hline \multicolumn{5}{|c|}{ Covid-19 ile ilgili alınan önlemleri yeterli bulma durumu } \\
\hline Evet & 52 & $\begin{array}{c}34 . \\
0\end{array}$ & $2.41 \pm .88$ & $.40 \pm .47$ \\
\hline Hayır & 30 & $\begin{array}{c}19 . \\
6\end{array}$ & $2.39 \pm .82$ & $.73 \pm .59$ \\
\hline Kismen & 71 & $\begin{array}{c}46 . \\
4\end{array}$ & $2.64 \pm .86$ & $.67 \pm .50$ \\
\hline Test/P & & & $\mathrm{KW}=2.961 \mathrm{p}=.228$ & $K W=13.131 p=.001$ \\
\hline
\end{tabular}

Tablo 3'e göre, Covid-19 tanısı alma durumu ile Beck anksiyete ölçeği arasında istatistiksel olarak anlamlı bir fark vardır $(\mathrm{p}<.05)$. Tanı alan tarım işçilerinin anksiyeteleri, tanı almayanlara göre yüksektir. Covid-19 tanısı alan yakını olma durumu ile Beck anksiyete ölçeği arasında istatistiksel olarak anlamlı bir fark vardır $(\mathrm{p}<.05)$. Tanı alan yakına sahip olan tarım iş̧̧ilerinin anksiyeteleri daha yüksektir.

Covid-19 hakkında yeterli bilgiye sahip olduğunu düşünme durumu ile Covid-19 korkusu ve Beck anksiyete ölçekleri arasında istatistiksel olarak anlamlı bir fark vardır ( $\mathrm{p}<.05)$. Covid-19 ölçeği ve Beck Anksiyete ölçeğine göre, Covid-19 hakkında yeterli bilgiye sahip olan tarım işçileri ile kararsız olan tarım işçileri arasında $(p=.026 ; p=.000)$ istatistiksel olarak anlamlı bir fark vardır $(\mathrm{p}<.05)$. Bu düşünceye sahip tarım işçilerinin her iki ölçek puan ortalaması yüksek bulunmuştur.

Covid-19 ile ilgili alınan bilginin kaynağı ile Beck anksiyete ölçeği arasında istatistiksel olarak anlamlı bir fark vardır $(\mathrm{p}<.05)$. Bilgiyi aileden alan tarım işçileri ile sağlık bakanlığından, medya kuruluşlarından, sosyal medyadan alan işçiler arasında $(\mathrm{p}=.004 ; \mathrm{p}=.034 ; \mathrm{p}=.024)$ istastistiksel olarak anlamlı bir fark vardır $(\mathrm{p}<.05)$. Bilgiyi, aileden alan tarım işçilerinin Beck anksiyete ölçeği puan ortalaması daha yüksektir.

Covid-19 ile ilgili alınan önlemleri yeterli bulma durumu ile Beck anksiyete ölçeği arasında istatistiksel olarak anlamlı bir fark vardır $(\mathrm{p}<.05)$. Covid-19 için alınan önlemleri yeterli bulan tarım işçileri ile yeterli bulmayanlar ve kısmen yeterli bulanlar arasında $(\mathrm{p}=.040 ; \mathrm{p}=.011)$ istatistiksel olarak anlamlı bir fark vardır $(\mathrm{p}<.05)$. Covid-19 için alınan önlemleri yeterli bulmayan tarım işçilerinin Beck anksiyete ölçeği puan ortalaması daha yüksektir. 
Tablo 4. Tarım İşçilerinin Kişisel Koruyucu Kullanımına Yönelik Farkındalıklarına Göre Covid-19 Ölçeği ve Beck Anksiyete Ölçeği Puan Dağgllımı (n=153)

\begin{tabular}{|c|c|c|c|c|}
\hline & $\mathbf{n}$ & $\%$ & $\begin{array}{c}\text { Covid-19 } \\
\text { Korkusu Ölçeği } \\
\text { X } \pm \text { SS } \\
\end{array}$ & $\begin{array}{c}\text { Beck Anksiyete } \\
\text { Ölçeği } \\
\text { X } \pm \text { SS } \\
\end{array}$ \\
\hline \multicolumn{5}{|c|}{ Findık toplarken sosyal mesafeye dikkat etme durumu } \\
\hline Dikkat eden & 22 & 14.4 & $2.36 \pm .87$ & $.30 \pm .37$ \\
\hline Dikkat etmeyen & 64 & 41.8 & $2.71 \pm .95$ & $.71 \pm .61$ \\
\hline Kararsiz & 67 & 43.8 & $2.37 \pm .74$ & $.57 \pm .45$ \\
\hline Test/P & & & $\begin{array}{c}\mathrm{KW}=4.515 \mathrm{p}= \\
.105\end{array}$ & $\mathrm{KW}=9.894 \mathrm{p}=.007$ \\
\hline \multicolumn{5}{|c|}{ Findık toplarken maske kullanımına dikkat etme durumu } \\
\hline Dikkat eden & 18 & 11.8 & $2.22 \pm 1.01$ & $.28 \pm .37$ \\
\hline Dikkat etmeyen & 76 & 49.7 & $2.70 \pm .95$ & $.66 \pm .60$ \\
\hline Kararsiz & 59 & 38.6 & $2.37 \pm .62$ & $.59 \pm .42$ \\
\hline Test/P & & & $\begin{array}{c}\mathrm{KW}=6.042 \mathrm{p}= \\
.049\end{array}$ & $\mathrm{KW}=\mathbf{9 . 8 1 7} \mathrm{p}=.007$ \\
\hline \multicolumn{5}{|c|}{ Maskeyi değiştirme sıklığı } \\
\hline 4 saatte bir & 62 & 40.5 & $2.64 \pm .91$ & $.62 \pm .53$ \\
\hline 8 saatte bir & 67 & 43.8 & $2.40 \pm .77$ & $.62 \pm .53$ \\
\hline 12 saat ve üzeri & 24 & 15.7 & $2.51 \pm .97$ & $.41 \pm .47$ \\
\hline Test/P & & & $\begin{array}{c}\mathrm{KW}=2.619 \mathrm{p}= \\
.270\end{array}$ & $\mathrm{KW}=3.588 \mathrm{p}=.166$ \\
\hline \multicolumn{5}{|c|}{ Maskeye erişimde sıkıntı yaşama durumu } \\
\hline Yaşayan & 17 & 11.1 & $3.01 \pm .79$ & $.76 \pm .73$ \\
\hline Yaşamayan & 95 & 62.1 & $2.37 \pm .81$ & $.48 \pm .43$ \\
\hline Kısmen yaşayan & 41 & 26.8 & $2.63 \pm .93$ & $.78 \pm .57$ \\
\hline Test/P & & & 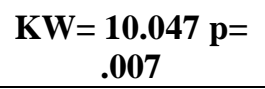 & $K W=8.186 p=.017$ \\
\hline
\end{tabular}

Diğer işçilerle bir aradayken sosyal mesafe ve maske önlemlerine uyma durumu

$\begin{array}{lcccc}\text { Uyan } & 29 & 19.0 & 2.32 \pm 1.05 & .36 \pm .45 \\ \text { Uymayan } & 51 & 33.3 & 2.70 \pm .91 & .76 \pm .61 \\ \text { Kismen uyan } & 73 & 47.7 & 2.46 \pm .72 & .56 \pm .45 \\ & & & \text { KW= }=4.463 \mathrm{p}=\quad \mathbf{K W}=\mathbf{1 1 . 1 6 0} \mathbf{p =}\end{array}$

Test/P

.107
.004

\begin{tabular}{|c|c|c|c|c|}
\hline \multicolumn{5}{|c|}{ Findık toplarken sık ve az vardiya ile çalışma durumu } \\
\hline Evet & 7 & 4.6 & $2.36 \pm .79$ & $.08 \pm .10$ \\
\hline Hayır & 109 & 71.2 & $2.51 \pm .87$ & $.60 \pm .55$ \\
\hline Kismen & 37 & 24.2 & $2.56 \pm .85$ & $.65 \pm .46$ \\
\hline Test/P & & & $\mathrm{KW}=.357 \mathrm{p}=.836$ & $\mathrm{KW}=\underset{.005}{10.517} \mathrm{p}=$ \\
\hline \multicolumn{5}{|c|}{ Hastalığın kendisine bulașacağını düșünme durumu } \\
\hline Evet & 84 & 54.9 & $2.78 \pm .86$ & $.70 \pm .59$ \\
\hline Hayır & 69 & 45.1 & $2.19 \pm .75$ & $.46 \pm .40$ \\
\hline Test/P & & & $\begin{array}{c}\mathrm{U}=1702.500 \mathrm{p}= \\
.00\end{array}$ & $\begin{array}{c}\mathrm{U}=\underset{\mathrm{C} 2323.500}{\mathrm{p}}= \\
.035\end{array}$ \\
\hline \multicolumn{5}{|c|}{ Kendini güvende hissetme durumu } \\
\hline Evet & 24 & 15.7 & $1.86 \pm .69$ & $.24 \pm .35$ \\
\hline Hayır & 129 & 84.3 & $2.63 \pm .84$ & $.65 \pm .53$ \\
\hline Test/P & & & $\mathrm{U}=\mathbf{7 2 8 . 5 0 0} \mathrm{p}=.00$ & $\mathrm{U}=744.500 \mathrm{p}=.00$ \\
\hline
\end{tabular}

Tablo 4'e göre, findık toplarken sosyal mesafeye dikkat etme durumu ile Beck anksiyete ölçeği arasında istatistiksel olarak anlamlı bir fark vardır $(\mathrm{p}<.05)$. Fındık toplarken sosyal mesafeye dikkat edildiğini düşünenler ile dikkat edilmediğini düşünenler ve kararsız kalanlar arasında $(\mathrm{p}=.001 ; \mathrm{p}=.029)$ istatistiksel olarak anlamlı bir fark vardır $(\mathrm{p}<.05)$. Fındık toplarken sosyal mesafeye dikkat edilmediğini düşünen tarım işçilerinin Beck anksiyete ölçeği puan ortalaması daha yüksek bulunmuştur.

Fındık toplarken maske kullanımına dikkat etme durumu ile Covid-19 korkusu ve Beck anksiyete ölçekleri arasında istatistiksel olarak anlamlı bir fark vardır $(\mathrm{p}<.05)$. Fındık toplarken maske kullanımına dikkat edildiğini düşünenler ile kararsız kalanlar arasında $(\mathrm{p}=$.048) Covid-19 korkusu ölçeğine göre istatistiksel olarak anlamlı bir fark vardır $(\mathrm{p}<.05)$. Fındık toplarken maske kullanımına dikkat edildiğini düşünenler ile edilmediğini düşünenler ve kararsız kalanlar arasında $(\mathrm{p}=.004 ; \mathrm{p}=.017)$ Beck anksiyeti ölçeğine göre istatistiksel olarak anlamlı bir fark vardır ( $\mathrm{p}<.05)$. 
Fındık toplarken maske kullanımına dikkat edilmediğini düşünen tarım işçilerinin hem Covid-19 korkusu ölçeği hem de Beck anksiyete ölçeği puan ortalamalarının daha yüksek olduğu bulunmuştur.

Maskeye erişimde sıkıntı yaşama durumu ile Covid-19 korkusu ve Beck anksiyete ölçekleri arasında istatistiksel olarak anlamlı bir fark vardır $(\mathrm{p}<.05)$. Maske erişiminde sıkıntı yaşamayanlar ile sıkıntı yaşayanlar arasında $(\mathrm{p}=.018)$ Covid-19 korkusu ölçeğine göre istatistiksel olarak anlamlı bir fark vardır $(\mathrm{p}<.05)$. Maske erişiminde sıkıntı yaşamayanlar ile kısmen sıkıntı yaşayanlar arasında $(\mathrm{p}=.010)$ Beck anksiyete ölçeğine göre istatistiksel olarak anlamlı bir fark vardır $(\mathrm{p}<.05)$. Maske erişiminde kısmen sıkıntı yaşayan tarım işçilerinin Beck anksiyete ölçeği puan ortalaması daha yüksek bulunmuştur.

Diğer işçilerle bir aradayken sosyal mesafe ve maske önlemlerine uyma durumu ile Beck anksiyete ölçeği arasında istatistiksel olarak anlamlı bir fark vardır $(\mathrm{p}<.05)$. Sosyal mesafe ve maske önlemlerine uyanlar ile uyamayanlar arasında $(\mathrm{p}=.004)$ istatistiksel olarak anlamlı bir fark vardır $(\mathrm{p}<.05)$. Önlemlere uyan tarım işçilerinin Beck anksiyete ölçeği puan ortalaması daha yüksek bulunmuştur.

Fındık toplarken sık ve az vardiya ile çalışma durumu ile Beck anksiyete ölçeği arasında istatistiksel olarak anlamlı bir fark vardır $(\mathrm{p}<.05)$. Fındık toplarken vardiya ile çalışmanın mümkün olduğunu düşünenler, düşünmeyenler ve kısmen mümkün diyenler arasında $(\mathrm{p}=.000)$ istatistiksel olarak anlamlı bir fark vardır $(\mathrm{p}<.05)$. Findık toplarken vardiya ile çalışmanın kısmen mümkün olduğunu düşünen tarım işçilerinin Beck anksiyeti ölçeği puan ortalaması daha yüksek bulunmuştur.

Hastalığın kendisine bulaşacağını düşünme durumu ile Covid-19 korkusu ve Beck anksiyete ölçekleri arasında istatistiksel olarak anlamlı bir fark vardır $(\mathrm{p}<.05)$. Hastalığın kendisine bulaşacağını düşünen tarım işçilerinin Covid19 korkusu ölçeği ve Beck anksiyete ölçeği puan ortalamaları bulaşmayacağını düşünenlere göre daha yüksek bulunmuştur.

Kendini güvende hissetme durumu ile Covid-19 korkusu ve Beck anksiyete ölçekleri arasında istatistiksel olarak anlamlı bir fark vardır $(\mathrm{p}<.05)$. Kendilerini güvende hissetmeyen tarım işçilerinin Covid-19 korkusu ölçeği ve Beck anksiyete ölçeği puan ortalamaları güvende hissedenlere göre daha yüksek bulunmuştur.

\section{Tartışma}

İstihdamda önemli bir yeri olan tarım sektörü, insan gücüne yoğun olarak ihtiyaç duymaktadır. Tarımsal üretimde farklı kollarda çalışan tarım işçilerinin yaşadığı bazı sorunlar vardır (4). Bu bölümde tarım işçilerinin pandemi sürecinde yaşadıkları riskler göz önüne alındığında mevcut sorunların yanı sıra Covid-19 süreci boyunca kişisel koruyucu kullanımı ve yaşanabilecek korku ve endişe sorunları tartışılmıştır.

Çalışmada, tarım ișçilerinin Covid-19 korkusu ölçek puanı 17.62 \pm 6.06 olarak bulunmuştur. Almanya'da 18 yaşından büyük erişkinlerle yapılan bir çalışmada katılımcıların Covid-19 korkusunun oldukça yüksek olduğu ifade edilmiştir (23). Doğu Avrupa'da yapılan bir çalışmada katılımcıların bu çalışma ile benzer olarak $17.40 \pm 4.70$ puan aldıkları görülmüştür (24). Literatür bu yönüyle çalışmamızı desteklemektedir. Çalışmada, tarım işçilerinin Beck anksiyete ölçeği puan ortalaması $12.47 \pm 11.13$ olarak bulunmuştur. İşçilerin anksiyete düzeylerine bakıldığında \%51.6'sı normaldir. Çin'de öğrencilerle yapılan bir çalışmada, öğrencilerin büyük çoğunluğun normal düzeyde anksiyeteye sahip olduğu; Almanya'da toplum içinde sağlık kaygısını belirlemek için yapılan bir çalışmada, katılımcıların orta düzeyde anksiyeteye sahip olduğu; İtalya'da genel ruh sağlığının değerlendirildiği bir çalışmada ise katılımcıların şiddetli anksiyeteleri olduğu ifade edilmiştir (25-27). Buna göre, çalışmamız literatürle benzediği kadar farklı sonuçlar olduğu da görülmektedir. Bu durumun sebebi, hedef nüfustaki kişisel farklılıklar, yaşanan stresli olaylar, stresli yaşam alanlarına verilen tepkilerin değişmesi ve geçmiş deneyimler olabilir.

Çalışmada, kadın tarım işçilerinin Covid-19 korkusu ölçeği puan ortalaması erkek tarım işçilerine göre daha yüksek bulunmuştur. Çalışmamızdaki bu bulgu literatürde pandemi süresinde korku, anksiyete ve risk algısı ile ilgili yapılan çalışmaların bulgularına benzemektedir $(12,24,27,28)$.

Çalışmada, geliri giderden az olan tarım işçilerinin Covid-19 korkusu ölçeği puan ortalaması daha yüksek bulunmuştur. Literatür pandemi gibi önemli bir halk sağlı̆̆ sorununun toplumun sosyodemografik durumu ile savunmasız olma, korku ve stres durumlarının ilişkili olduğunu ifade etmektedir $(29,30)$. Çalışmamız dolaylı olarak literatürü desteklemektedir.

Çalışmada, geniş aile yapısına sahip olan tarım işçilerinin çekirdek aile yapısına sahip olanlara göre Beck anksiyete puan ortalaması daha yüksek bulunmuştur. Yapılan kısıtlı çalışmada benzer özellikte bir sonuca rastlanmamıştır. Bu bulguya göre ailede kişi sayısı arttıkça riskin de artacağı, bu durumun pandemi sürecindeki anksiyeteyi artırabileceği söylenebilir.

Çalışmada, tarım işçilerinin \%33.1'i fındık bahçesinde Covid-19 ile ilgili yapılması gereken iyileştirmelerin başında hijyen koşulları geldiğini ifade etmektedir. Centers for Disease Control and Prevention (CDC) tarım işçileri ile ilgili yayınladığı bir kılavuzda benzer olarak temiz su ve sanitasyon ile hijyen koşullarında iyileştirilmeler yapılması gerektiğini vurgulamıştır (31). Tarım işçilerinin ifade ettiği iyileştirmelerin başında hijyen koşullarının gelmesi beklenen bir durum olup güncel Covid-19 yaklaşımlarına uygun olduğunu göstermektedir.

Çalışmada, kendisi ve yakını Covid-19 tanısı alan tarım işçilerinin anksiyeteleri tanı almayanlara göre daha yüksektir. Pandemi sürecinde bireylerin hem kendisi hem ailesi için bu enfekte olmanın önemli bir risk olarak görüldüğü bildirilmektedir (30). İki farklı ülkeden yüksek katılımcı sayısı ile gerçekleşen bir çalışmada, katılımcılar pandemi sürecinde kendisi ve yakınları için endişe yaşadıklarını ifade etmiştir (32). Pandemi sürecinde yetişkinlerde anksiyete ve umutsuzluk durumunun incelendiği bir başka çalışmada, katılımcıların dörtte biri anksiyete yaşadıklarını ifade etmiştir (33). Kişilerin anksiyete yaşaması pandemi sürecinin belirsizliğinden ötürü beklenen sonuçlardan biridir. Bu sebeple çalışmanın bu bulgusu literatürü destekler niteliktedir. 
Çalışmada, Covid-19 hakkında kararsız bilgiye sahip olduğunu düşünen tarım işçilerinin Covid-19 korkusu ölçeği puan ortalaması daha yüksek bulunmuştur. Covid-19 hakkında yeterli bilgiye sahip olmadığını düşünen tarım işçilerinin Beck anksiyete ölçeği puan ortalaması daha yüksek bulunmuştur. Bu bilgiyi, aileden alan tarım işçilerinin ölçek puanı ise daha yüksektir. Covid-19 süreciyle ilgili net ve yeterli bilgiye sahip olmayan bireyler hem korku hem de anksiyete yaşayabilmektedir. Burada dikkat çeken durum aileden alınan Covid-19 bilgisinin ölçek puanlarını etkilemesidir. Literatürde benzer durumun sorgulandığ bir pandemi durumunda bireylerin korku ve anksiyete yaşaması öngörülebilir bir sonuçtur.

Çalışmada, Covid-19 için alınan önlemleri yeterli bulmayan ve findık toplarken sosyal mesafeye dikkat edilemediğini düşünen tarım işçilerinin Beck anksiyete ölçeği puan ortalaması daha yüksek bulunmuştur. Ayrıca findık toplarken maske kullanımına dikkat edilemediğini düşünen tarım işçilerinin hem Covid-19 korkusu ölçeği hem de Beck anksiyete ölçeği puan ortalamaları daha yüksek olduğu bulunmuştur. Pandemi süresince yaşanan korku, anksiyete, stres gibi durumlarının kişisel koruyucu kullanım alışkanlıklarını etkilediği bildirilmektedir (19). Covid-19 sürecinde yetişkinlerde davranış değişikliği ve korku ilişkisinin incelendiği bir çalışmada, halk sağlığını koruyucu önlemlerin korku ve endişe durumlarıyla ilişkili olduğu; pandemide yetişkinlerin anksiyete ve umutsuzluk durumunun incelendiği bir başka çalışmada, benzer sonuçlara ulaşıldığı ifade edilmiştir $(33,34)$. Konuyla ilgili yapılan az sayıdaki çalışmanın bulguları bu çalışmayı destekler niteliktedir.

Çalışmada, tarım işçilerinin çoğu diğer işçilerle findık toplarken sosyal mesafe ve maske önemlerine kısmen uyulduğunu, az ve sık vardiya ile çalışmanın mümkün olmadığını düşünmektedir. Tarım sektöründe maske kullanımı, sosyal mesafe ve aralıklı çalışma şeklindeki kişisel koruyucu yöntemler çoğu zaman yetersiz kalmaktadır. Burada önemli olan CDC'nin vurguladığı gibi verilen araların çoğaltılması, maske ve mesafe için kontrol planlarının oluşturulmasıdır (31). Nitekim yapılan açıklamalarda kişisel koruyucu ekipman ve sosyal mesafenin oldukça yararlı olduğu vurgulanmaktadır $(35,36)$. Ayrıca bu düşüncedeki tarım işçilerinin Beck anksiyeti ölçeği puan ortalaması daha yüksek bulunmuştur. Bu durum kişisel koruyucu tedbirlerin eksikliğinin anksiyeteye neden olduğunu göstermektedir. Yapılan bir çalışmada mesleğin ve bu meslekte alınan tedbirlerin anksiyete ile ilişkisi olduğu; başka bir çalışmada sosyal mesafe ve maske kullanımının anksiyete ile ilişkilendirildiği ifade edilmiştir $(37,38)$.

Çalışmada, maskeye erişimde sıkıntı yaşamayan tarım işçileri ile sıkıntı yaşayanlar arasında Covid-19 korkusu ölçeğine göre önemli bir fark vardır. Beck anksiyete ölçeğine göre, maskeye erişimde sıkıntı yaşamayan tarım işçileri ile kısmen sıkıntı yaşayanlar arasında önemli bir fark vardır. Çin'de yapılan bir çalışma, alınan koruyucu önlemlerin endişe ve korkuyu azalttığını ortaya çıkarmıştır (39). Buna göre, maskenin önemli bir kişisel koruyucu olarak benimsenmesi ve maskeye erişimde yaşanan aksaklıkların kişilerde korku ve anksiyete yaratabileceği düşünülebilir.

Çalışmada, tarım işçilerinin \%54.9'u hastalığın kendilerine bulaşacağını düşünmekte ve \%84.3'ü kendilerini güvende hissetmediklerini belirtmektedir. Ayrıca bu düşüncedeki tarım işçilerinin Covid-19 korkusu ölçeği ve Beck anksiyete ölçeği puan ortalamaları daha yüksek bulunmuştur. Pandemi gibi riskin yüksek olduğu olağandışı durumlarda korku, endişe ve güven eksikliği yaşanabildiği bilinmektedir (40). Covid-19 nedeniyle toplumun büyük bir çoğunluğun bu durumda olduğu ve tarım işçilerinin de hastalığa yakalanma ve güvende olmadığını düşünmelerinin beklenen bir durum olduğu söylenebilir. Almanya'da yapılan bir çalışmada, benzer olarak katılımcıların büyük çoğunluğu henüz hastalanmamış olmasına rağmen gelecekte hastalanacağını düşündüğünü ve kendilerini güvende hissetmediği ifade edilmiştir (23). Bangladeş’te yapılan bir çalışmada ise hem kendini hem yakın çevresini güvende hissetmeyen kişilerin korku ve anksiyeteleri yüksek olarak ifade edilmiştir (37).

\section{Sonuçların Uygulamada Kullanımı}

Çalışmaya katılan tarım işçileri Covid-19 sürecinde gereken iyileştirmelerin başında hijyen koşullarının geldiğini düşünmektedir. Tarım işçilerinin \%54.9'u bu hastalığı yaşayacağını ve \%84.3'ü kendini güvende hissetmediğini ifade etmektedir. Tarım işçilerinin Covid-19 korkularının orta düzeyde olduğu, \%51.6'sının normal düzeyde anksiyeteleri olduğu ve cinsiyet, aile yapısı, gelir düzeyi gibi demografik değişkenlerle değiştiği görülmektedir. Ayrıca kişisel koruyucu kullanımı, sosyal mesafe, vardiya ile çalışma durumları ile korku ve endişeleri arasında ilişki olduğu görülmektedir.

Tarım işçilerinin Covid-19 sürecinde bütüncül bakış açısıyla değerlendirildiği bu çalışmada, bakımda kaliteyi sağlamanın yanı sıra bulaşıcı hastalıklarla mücadelede ön saflarda olan, çalışan sağlığını koruma ve geliştirmede rol ve sorumlukları bulunan halk sağlı̆̆ı hemşirelerinin sürece verebileceği katkılar ortaya koyulmuştur. Multidisipliner olarak yapılacak benzer nitelikteki çalışmaların literatürü destekleyeceği düşünülmektedir.

Covid-19 pandemisi boyunca tarım işçilerinin dahil olduğu yerel yönetimler saha içinde denetlemelerde bulunmalıdır. Risklerin belirlenmesi, önlemlerin alınması ve olası enfeksiyonlara karşı işbirliği içinde hareket edilmelidir. İşveren tarafından çalışma sahasındaki olası iyileştirilmeler en kısa sürede tamamlanarak hayata geçirilmelidir. Özellikle kişisel koruyucu ekipmanların kolay ulaşılabilir olması gerekmektedir. Yaşanabilecek bulaş durumlarında sağlık ekibi ile koordineli hareket edilmesi, temel eğitimlerin bir uzman tarafından verilmesi önerilmektedir. Bu konuda bir halk sağlı̆̆ı hemşiresinin dahil olduğu multidisipliner ekibin kurulması ve yapılan eğitimlerin artırılmasına önem verilmelidir. Ayrıca benzer çalışmaların artırılması önerilmektedir.

\section{Kisitlılıklar}

Bu çalışma, seçilen örneklem sebebiyle 2020 yılı fındık sezonunda tarım işçisi olarak çalışan kişileri ve bulunduğu bölgeyi temsil etmektedir. Ayrıca alanda yapılan çalışmaların azlığı nedeniyle çalışmanın tartışması kısıtlı bir literatür ile yapılmıştır.

\section{Bilgilendirme}

Yazarların araştırmaya katkı oranı beyanları şu şekildedir; araştırmanın konusu ve metodolojisinin belirlenmesi İAA, 
$\mathrm{AH}$; verilerin toplanması ve işlenmesi $\mathrm{AH}$; verilerin analizi ve yorumlanması İAA, AH; makalenin yazılması İAA, AH. Çalışma için herhangi bir fon desteği alınmamış ve bütçe araştırmacılar tarafından karşılanmıştır. Araştırmacılar arasında herhangi bir çıkar çatışması bulunmamaktadır. Bu çalışmanın yürütülebilmesi için bir üniversitenin Sosyal ve Beşeri Bilimler Etik Kurulu’ndan (Tarih: 30.10.2020, Karar Sayısı: 2020/665) onay alınmıştır. 


\section{Kaynaklar}

1. Azoulay E, Kentish-Barnes NA. 5-point strategy for improved connection with relatives of critically ill patients with COVID-19. Lancet Psychiatry 2020;8(6):e52.

2. Jiang X, Deng L, Zhu Y, Ji H, Tao L, Liu L, et al. Psychological crisis intervention during the outbreak period of new coronavirus pneumonia from experience in Shanghai. Psychiatry Research 2020; 286:112903.

3. Khan U, Mehta R, Arif M, Lakhani O. Pandemics of the past: A narrative review. J Pak Med Assoc. 2020;70(5):347.

4. Fereli S, Aktaç Ş, Güneş F. Mevsimlik tarım işçilerinin çalışma koşulları, beslenme durumları ve görülen sorunlar. Gazi Sağlık Bilimleri Dergisi 2016;1(3):36-47.

5. ILO. Agricultural workers and their contribution to sustainable agriculture and rural development. 2007. URL: http://www.ilo.org/wcmsp5/groups/public/@ed_dialogue/@actrav/documents/publication/wcms_113732.pdf 08.08.2020.

6. Görücü İ, Akbıyık N. Türkiye'de mevsimlik tarım işçiliği: Sorunları ve çözüm önerileri. Hikmet Yurdu DüşünceYorum Sosyal Bilimler Araştırma Dergisi 2010;3(5):189-220.

7. Bayramoğlu Z, Bozdemir M. Tarım sektöründe işgücü terminolojisinin tanımlanması. Türk Tarım-Gıda Bilim ve Teknoloji Dergisi 2020;8(3):773-83.

8. Baş L, Ulukan NC. Seasonal local female workers in hazelnut agriculture: The case of Fatsa. Fiscaoeconomia 2020;4(1):111-31.

9. Kablay S, Aysan ME. Fındık işçileri ve sorunları. Humanities\&Social Sciences 2019;143.

10. Dennerlein JT, Burke L, Sabbath EL, Williams JA, Peters SE, Wallace L, ... \& Sorensen G. An integrative total worker health framework for keeping workers safe and healthy during the COVID-19 pandemic. Human Factors 2020;62(5):689-96.

11. Aslan R. Covid-19 fizyoloji ve psikolojiyi nasil etkiliyor?. Ayrıntı Dergisi 2020;8(88):47-53.

12. Ekiz T, Ilıman E, Dönmez E. Bireylerin sağlık anksiyetesi düzeyleri İle Covid-19 salgını kontrol algısının karşılaştırılması. Uluslararası Sağlık Yönetimi ve Stratejileri Araştırma Dergisi 2020;6(1):139-54.

13. Özyürek A, Atalay D. Covid-19 pandemisinde yetişkinlerde yaşamın anlamı ve ölüm kaygısı ile iyilik hali arasındaki ilişkinin incelenmesi. Turan: Stratejik Arastırmalar Merkezi 2020;12(46):458-72.

14. Özdin S, Bayrak Özdin Ş. Levels and predictors of anxiety, depression and health anxiety during COVID-19 pandemic in Turkish society: The importance of gender. International Journal of Social Psychiatry 2020;66(5):50411.

15. Howard J. Nonstandard work arrangements and worker health and safety. American Journal of Industrial Medicine 2017;60:1-10.

16. Mertol H, Akgeyik M, Pirdoğan A, Karaman N. Mevsimlik tarım işçiliği sorunları ve çözüm önerileri (Hilvan Örneği). Eğitim Bilim ve Araştırma Dergisi 2021;2(1):63-74.

17. Güven Tezcan S. Temel Epidemiyoloji. 1. Basım. Ankara Hipokrat Kitabevi; 2017.

18. Alıcılar HE, Güneş G, Çöl M. Toplumda COVID-19 pandemisiyle ilgili farkındalık, tutum ve davranışların değerlendirilmesi. ESTÜDAM Halk Sağlığı Dergisi 2020;5:1-16.

19. Ahorsu DK, Lin CY, Imani V, Saffari M, Griffiths MD, Pakpour AH. (2020). The fear of COVID-19 Scale: Development and initial validation. International Journal of Mental Health and Addiction 2020;1-9.

20. Bakioğlu F, Korkmaz O, Ercan H. Fear of COVID-19 and positivity: Mediating role of intolerance of uncertainty, depression, anxiety, and stress. International Journal of Mental Health and Addiction 2020;1-14.

21. Beck AT, Epstein N, Brown G, Ster RA. Aninventory for measuring clinical anxiety: psychometric properties. J Consul Clin Psychol 1988; 56:893-7.

22. Ulusoy M, Şahin N, Erkman H. Turkish version of the beck anxiety inventor, psychometric properties. Journal of Cognitive Psychotherapy: An International Quarterly 1998;12(2):28-35.

23. Gerhold L. COVID-19: Risk perception and coping strategies. 2020; 10.31234/osf.io/xmpk4

24. Reznik A, Gritsenko V, Konstantinov V, Khamenka N, Isralowitz R. COVID-19 fear in Eastern Europe: Validation of the fear of COVID-19 Scale. International Journal of Mental Health and Addiction 2020;1-6.

25. Cao W, Fang Z, Hou G, Han M, Xu X, Dong J, et al. The psychological impact of the COVID-19 epidemic on college students in China. Psychiatry Research 2020;112934.

26. Jungmann SM, Witthöft M. Health anxiety, cyberchondria, and coping in the current COVID-19 pandemic: Which factors are related to coronavirus anxiety?. Journal of Anxiety Disorders 2020;102239.

27. Rossi R, Socci V, Pacitti F, Di Lorenzo G, Di Marco A, Siracusano A, et al. Mental health outcomes among front and second line health workers associated with the COVID-19 pandemic in Italy. medRxiv 2020; https://doi.org/10.1101/2020.04.16.20067801

28. Wang C, Pan R, Wan X, Tan Y, Xu L, Ho CS, et al. Immediate psychological responses and associated factors during the initial stage of the 2019 coronavirus disease (COVID-19) epidemic among the general population in china. International Journal of Environmental Research and Public Health 2020;17(5):1729.

29. Aydemir D, Ulusu NN. Influence of lifestyle parameters-dietary habit, chronic stress and environmental factors, jobs-on the human health in relation to the COVID-19 pandemic. Disaster Medicine and Public Health Preparedness 2020;1-2.

30. Stokes JE, Patterson SE. Intergenerational relationships, family caregiving policy, and COVID-19 in the United States. Journal of Aging \& Social Policy 2020;1-9. 
31. CDC. Agriculture workers and employers. 2020. URL: https://www.cdc.gov/coronavirus/2019ncov/community/guidance-agricultural-workers.html 11.09.2020.

32. Zettler I, Schild C, Lilleholt L, Kroencke L, Utesch T, Moshagen M, et al. The role of personality in Covid-19 related perceptions, evaluations, and behaviors: Findings across five samples, nine traits, and 17 criteria. Psyarxiv 2020. URL: https://psyarxiv.com/pkm2a/ 10.02.2021

33. Erdoğdu Y, Koçoğlu F, Sevim C. COVID-19 pandemisi sürecinde anksiyete ile umutsuzluk düzeylerinin psikososyal ve demografik değişkenlere göre incelenmesi. Klinik Psikiyatri Dergisi 2020; 23:1.

34. Harper CA, Satchell LP, Fido D, Latzman RD. Functional fear predicts public health compliance in the COVID19 pandemic. International Journal of Mental Health and Addiction 2020;1-14.

35. Semple S, Cherrie JW. COVID-19: Protecting worker health. Annals Of Work Exposures And Health 2020;64(5):461-4.

36. Smereka J, Szarpak L. The use of personal protective equipment in the COVID-19 pandemic era. The American Journal of Emergency Medicine 2020; 38:1515-39.

37. Islam SDU, Bodrud-Doza M, Khan RM, Haque MA, Mamun MA. Exploring COVID-19 stress and its factors in Bangladesh: A perception-based study. Heliyon 2020; 6(7):e04399.

38. Olivera-La Rosa A, Chuquichambi EG, Ingram, GP. Keep your (social) distance: Pathogen concerns and social perception in the time of COVID-19. Personality and Individual Differences 2020; 166:110200.

39. Qian M, Wu Q, Wu P, Hou Z, Liang Y, Cowling BJ, et al. Psychological responses, behavioral changes and public perceptions during the early phase of the COVID-19 outbreak in China: A population based cross-sectional survey. medRxiv 2020; https://doi.org/10.1101/2020.02.18.20024448.

40. Cori L, Bianchi F, Cadum E, Anthonj C. Risk perception and COVID-19. Int. J. Environ. Res. Public Health 2020;17(9):3114. 